3-2018

\title{
Persistence at a Tribal University: Factors Associated With Second Year Enrollment
}

Thomas C. Motl

University of North Dakota, thomas.motl@UND.edu

Karen D. Multon

Fei Zhao

\section{How does access to this work benefit you? Let us know!}

Follow this and additional works at: https://commons.und.edu/ehb-fac

Part of the Higher Education Commons, and the Indigenous Education Commons

\section{Recommended Citation}

Thomas C. Motl, Karen D. Multon, and Fei Zhao. "Persistence at a Tribal University: Factors Associated With Second Year Enrollment" (2018). Education, Health \& Behavior Studies Faculty Publications. 3.

https://commons.und.edu/ehb-fac/3

This Article is brought to you for free and open access by the Department of Education, Health \& Behavior Studies at UND Scholarly Commons. It has been accepted for inclusion in Education, Health \& Behavior Studies Faculty Publications by an authorized administrator of UND Scholarly Commons. For more information, please contact und.commons@library.und.edu. 


\title{
Persistence at a Tribal University: Factors Associated With Second Year Enrollment
}

Thomas C. Motl, University of British Columbia

Karen D. Multon and Fei Zhao, University of Kansas

\begin{abstract}
Participants include 89 college students from a tribal university in the Midwestern United States. A survey regarding attitudes and adjustment to campus was administered to all students during their first semester of college. Variables assessed included psychosociocultural integration factors, such as educational goals, trust of others at college, longing for home, school pride, and fair treatment from others (Motl et al., 2009). Objective variables indicating level of academic preparation for college (high school GPA, ACT scores, and class percentile), academic integration (college GPAs), and persistence (2nd-year enrollment status) were gathered from the university. Using logistic regression procedures, a model was created that accurately classified $89.9 \%$ of students into persisters and nonpersisters based on second-year enrollment status. The 3 blocks of variables - academic preparation, academic integration, and psychosociocultural integration factors - were entered sequentially into the model. Psychosociocultural variables were found to be predictive of persistence even after accounting for other variables in the model. High second semester GPA, placing an importance on education, staving off homesickness, perceptions of fair treatment from others, and school pride were all significant predictors of retention. Surprisingly, high school class percentile, trust of others at college, and levels of hope were all inversely associated with persistence behaviors.
\end{abstract}

Keywords: American Indians, college students, persistence, retention 
Statistics regarding American Indian ${ }^{1}$ secondary and postsecondary educational success indicate that American Indians have more difficulty navigating the institutions that comprise the American educational system than other minority groups. According to a report by Stillwell and Sable (2013), American Indians were most at risk for dropout during high school, with only a 69\% 4-year graduation rate. As a result, fewer American Indians are eligible for postsecondary education than any other group. For those who do enter postsecondary institutions, graduation rates for American Indians hover around 15\% in predominantly White institutions (PWIs), which is again lower than any other ethnic group (Freeman \& Fox, 2005).

In an attempt to provide more comprehensive educational opportunities for this population, tribal colleges and universities (TCUs) began to be established in the late 20th century. TCUs are federally funded and accredited institutions of higher education in the United States or Canada that receive their charters from a federally recognized tribe or tribes. They are seen as integral partners in the cultural and economic growth of tribal communities (Ah NeeBenham, 2003) and their curricula have been developed to emphasize the values, beliefs, traditions, and language of tribal communities (Pavel, Inglebret, \& Banks, 2001). In the 20092010 academic year, the 37 TCUs in the United States and Canada enrolled approximately 10\% $(19,070)$ of all indigenous college students, graduating 2,437 of them (American Indian Higher Education Consortium, 2012). Though the exact graduation rate across these institutions is difficult to calculate, some studies suggest TCUs graduate more than 20\% of American Indian

\footnotetext{
${ }^{1}$ The terms American Indian, Native American, and Native North American are all considered acceptable when referring to indigenous peoples of North America in scholarly literature (American Psychological Association, 2009). This study uses American Indian for the sake of referencing consistency, given that a large portion of the current literature employs this term.
} 
students (e.g., Patterson Cross, 2002; Rousey \& Longie, 2001), a higher rate than observed for this population at PWIs.

Most efforts to determine the barriers to persistence for American Indian students have been qualitative in nature (e.g., Guillory \& Wolverton, 2008; Jackson, Smith, \& Hill, 2003; see also Jenkins, 1999 and Larimore \& McClellan, 2005 for summaries of this research). A major limitation to the few quantitative studies is that they rely largely on subjective self-report measures of intention to persist, rather than actual, objective persistence behavior. Furthermore, most studies focus on American Indian students enrolled in PWIs, which differ greatly from TCUs in student-body makeup, cultural focus, and mission (see Pavel, Inglebret, \& Banks, 2001 for a review).

Robbins et al. (2004) conducted a metaanalysis that included 109 studies on college persistence and factors that predict college outcomes in general. This study has been one of the most comprehensive studies regarding college student achievements and persistence (Richardson, Abraham, \& Bond, 2012). However, in the 109 studies examined, only three were based on samples that consist of 100\% American Indian collegians. The general paucity of quantitative studies on American Indian college retention and college outcomes in general indicates that more studies of this kind and with this population are very much needed.

The current study is a longitudinal extension of previous research by Motl et al. (2009), in which 12 psychosociocultural factors were derived from data gathered from a sample of students during their first semester at a TCU. One year persistence information and grade point averages (GPA) for each student were added to the dataset for the current analyses. Psychosociocultural factors associated with persistence and precollege variables considered predictive of student success in college (e.g., high school GPA, ACT scores) were analyzed to 
produce a statistical model that predicted objective persistence behaviors in American Indian students enrolled in a tribal university. The purpose of this study is to address the question: What factors are predictive of student persistence at a tribally controlled university?

\section{Literature Review}

Initially, institutional researchers assumed that students withdrew from college as a result of poor academic performance, but early studies failed to provide substantial evidence of the relationship between dropout rates and academic performance. Tinto (1975) and Pascarella and Terenzini (1980) found that college dropout was more strongly related to college student integration. In his student integration model, Tinto suggested that students enter college with a specific set of academic, family, skill, and personality characteristics. The interaction of these characteristics with the institutional environment determines the student's integration. Students who are able to navigate institutional demands successfully integrate and are less likely to drop out of school (Terenzini \& Pascarella, 1991).

Tinto (1975, 1994) described two related, but distinct forms of integration: academic integration and psychosocial integration. Academic integration incorporates such constructs as academic preparation (the student's knowledge of content), study skills (the student's knowledge about the process of learning), desire and interest in college classes, academic self-efficacy, and commitment to educational goals. Psychosocial integration incorporates such constructs as the student's perceptions of and positive interactions with the institution, faculty and staff, success in establishing social networks, involvement in and enjoyment of the campus environment, and identification with the goals and values of the institution. According to Tinto, successful integration occurs when a student can thrive both academically and socially. Although there is general support for Tinto’s $(1975,1994)$ model for majority White populations at mainstream 
colleges and universities, there is some question as to how well Tinto's theory can be applied to historically underserved populations (Guiffrida, 2006). Tierney (1992), for example, objected to Tinto’s (1975) theory as applied to American Indian students, noting that the theory does not account for significant cultural dissonance that may exist for this population, and that by using such models, institutions implicitly pressure students to conform to dominant mores and values while abandoning other (i.e., ethnic or cultural) identities.

Due to these concerns, researchers (e.g., Guiffrida, 2006; Guiffrida, Marquez Kiyama, Waterman, \& Museus, 2012; Nora, 2001) have de-emphasized the role of student assimilation and focused on the role of institutional commitment to multiculturalism and inclusivity. For example, Museus, Lam, Huang, Kem and Tan (2012) described the need to include cultural integration as a third integrative factor influencing success and retention for students of color. This form of integration does not require students to abandon cultures of their home in favor of the predominant culture of the institution. In fact, the extent to which institutions value and promote the cultural assets (e.g., knowledge, relationships, traditions) students bring to the college environment will increase institutional commitment and foster student engagement (Nora \& Cabrera, 1996).

Acknowledging the need to include such cultural components for diverse populations, Gloria and Rodriguez (2000) have modified Tinto’s model; using the term "psychosociocultural” to denote this multifaceted domain of experience for racially diverse students. Thompson, Johnson-Jennings, and Nitzarim (2013) have argued that a psychosociocultural model of student persistence is appropriate for American Indian students in PWIs. The following is a review of the specific factors that have been empirically supported as effective promoters of American Indian persistence in higher education, dividing these factors into those that contribute to academic and 
psychosociocultural integration, thus aligning with a modified version of Tinto's student integration (e.g., Thompson et al., 2013).

\section{Academic Integration}

For the purposes of this study, academic integration was conceptualized as consisting of two components: academic preparation and academic performance. Academic preparation refers to the skills and knowledge a student possesses upon entering college. Academic performance is defined as the ability to successfully master coursework once at college.

Academic preparation. Citing an abundance of research, Lundberg (2007) concluded that students are more likely to enter college academically underprepared if they are: (a) economically disadvantaged, (b) of non-White racial minorities, and/or (c) from cultural backgrounds that differ from traditional collegiate environments. Lundberg noted that American Indian students, by definition, fit into at least one of these categories and often fall into all three. Pottinger (1989) stated that American Indian students were significantly less academically prepared than their White counterparts. However, after controlling for academic preparation, American Indian students who were able to maintain minimal academic standards were no more likely to drop out than White students. Hoover and Jacobs (1992) surveyed 257 American Indian students and found that their perceptions of their own study skills were less accurate than their self-perceptions in a number of other areas. American Indian students also report that lack of academic preparation was a significant barrier once they entered college (Guillory, 2009).

Brown and Robinson Kurpius (1997) concluded that academic preparation was one of the most important factors differentiating American Indian persisters and nonpersisters. They found that a single factor encompassing both student perceptions of their academic preparation and the 
level of education that student aspired to attain was a significant predictor of persistence behaviors while in college. Crissman Ishler and Upcraft (2004) stated that, regardless of ethnicity or background "the most powerful predictor of persistence into the sophomore year is the firstyear student’s prior academic achievement, including high school grades” (p. 33). In a review of the literature, Jenkins (1999) found that "precollege preparation” was one of the factors most often associated with American Indian student success in college.

Academic performance. College GPA is a direct indicator of a student's academic performance, and has been found to be one of the best predictors of a college student's persistence into their second year (Crissman Ishler \& Upcraft, 2004). Pottinger (1989) found that college GPA was the single most predictive factor of American Indian students' persistence behavior. This is not surprising, given that most colleges have academic standards to which they hold students accountable.

Furthermore, Lundberg (2007) stated that models of American Indian student success tend to place "emphasis on student engagement in educationally purposeful activities" (p. 405). Astin (1982), for instance, proposed that college GPA is not simply indicative of academic aptitude, but also of academic effort and engagement. A high GPA suggests student investment and involvement. Based on the current literature, academic performance, usually in the form of collegiate GPA, is an important predictor of persistence; and this finding may be especially true for American Indian students.

It should be noted, however, that Tinto’s $(1975,1994)$ model is based on voluntary student departure. It is meant to describe students who are prepared and able to succeed academically, and assumes that all students who meet admission standards also meet these criteria. As for many students of color, American Indian students may be less prepared to 
succeed academically than White students (Pottinger, 1989) and are more likely to be forced to disengage from school because of financial hardship or other external factors (Lundberg, 2007).

\section{Psychosociocultural Integration}

The academic variables previously noted may be considered traditional predictors of student persistence. In fact, they carry the most weight when administrators are making admission decisions, presumably because they believe them to be highly predictive of retention (Mallinckrodt, 1988). It has been recognized, however, that psychological, social and cultural factors exert powerful influence on student persistence (e.g., Tinto, 1994), and this may be particularly true for American Indian students (Thompson, Johnson-Jennings, \& Nitzarim, 2013).

Brown and Robinson Kurpius (1997) modified version of Tinto's model to include cultural components when investigating psychosociocultural integration variables in American Indian samples at a large American PWI. The researchers generated a model based on six factors: perceived discrimination, social integration, valuing of education, family encouragement, academic preparation/aspirations, and faculty and staff interactions. Together, these factors were able to correctly classify $67 \%$ of all participants into persisting and nonpersisting groups. Specifically, persistence was strongly associated with positive faculty and staff interactions and high educational aspirations. In general, although these findings offered limited support for Tinto's model, American Indian samples may need some different considerations when compared with White populations.

Gloria and Kurpius (2001) also conducted a study on American Indian student persistence in PWIs that was based on a modified version of Tinto's (1975) social integration model. They used Pascarella and Terenzini’s (1980) Persistence/ Voluntary Dropout Decisions 
Scale, an established measure known to be reliably associated with persistence decisions as an outcome variable. Results indicated that social support, including that from family, friends and faculty/ staff, was "the most powerful noncognitive factor in student persistence" (p. 99). Comfort in the university environment and self-beliefs were also determined to be important aspects of American Indian students experience at school. Particularly, faculty and staff encouragement and mentorship was found to be associated with positive outcomes. Although there is no difference between the academic and social effort of American Indian and White students, the efforts exerted by White students result in more successful integration than for their non-White counterparts (Larimore \& McClellan, 2005), suggesting social integration may be a more difficult process for American Indian students enrolled in mainstream colleges and universities.

Qualitative studies indicate family support, sense of tribal community, and on-campus social supports are predictive of American Indian college student persistence in the context of predominantly White institutions (Guillory \& Wolverton, 2008). After interviewing 15 American Indian college graduates, Jackson, Smith, and Hill (2003) found eight themes they identified as key to their success: family support, structured social support, faculty/staff approachability, exposure to vocational tracks, developing personal independence, finding spiritual resources, overcoming prejudice, adopting a nonlinear path, and dealing with paradoxical cultural pressure. Commitment to the institution and personal commitment to goals have also been identified as important indicators of American Indian persistence using both qualitative (e.g., Jackson, Smith, \& Hill, 2003), and quantitative (e.g., Wells, 1997) studies.

American Indian persistence was also directly connected to peer mentoring (Shotton, Oosahwe, \& Cintrón, 2007). The effects of prolonged, academically enhancing interactions are 
likely protective for a number of reasons, including fostering personal and institutional commitments. These bonds were found to increase trust and investment in the university as a whole. It appears that students who feel that the university and its constituents have meaningfully invested in them, will return the investment (Huffman \& Ferguson, 2007; Lundberg, 2007). An institutional commitment to fairness and diversity aids the integration process (Okagaki, Helling, \& Bingham, 2009).

Thompson, Johnson-Jennings, and Nitzarim (2013) applied Gloria and Rodriguez’s (2000) psychosociocultural model of student persistence to American Indian populations. The model comprises psychological, social, and cultural dimensions. The psychological dimension includes collective self-esteem, self-efficacy for coping with educational barriers, and motivational influences. The social support dimension includes support from the primary caregiver, and community connections. The cultural dimension includes feelings of separation and alienation from others. Thompson, Johnson- Jennings, and Nitzarim (2013) developed an instrument based on this model, and surveyed 156 American Indian students from around the United States. They found that only three factors— one from each dimension—were predictive of student intentions to persist: self-efficacy for coping with educational barriers at college (psychological dimension), community connections on campus (social support dimension), and separation and alienation from community of origin (cultural dimension). Exploring the role of cultural and social supports in student development, Kenny and Stryker (1996) found that social adjustment to college for ethnically diverse students was primarily a function of the strength of family support networks; whereas social adjustment was more strongly related to college friendship networks for White students. 
Importantly, however, these studies have taken place in the context of institutions in which American Indian students are a minority population. Nora and Cabrera (1996) found that perceptions of prejudice and discrimination are common among American Indians enrolled in mainstream institutions, and that these perceptions have a direct effect on persistence decisions.

Few studies have been conducted examining psychosociocultural factors affecting persistence behaviors of students at TCUs, and a literature review of the extant literature uncovered no studies using quantitative methods with TCU samples. Ness (2002) conducted a qualitative study of American Indian persisters and nonpersisters from a TCU. Successful students were more likely to: live near the location of the school; attend a college that was an active cultural center; have access to administrative support services (e.g., admissions, registration, financial aid); attain financial aid; have contact with American Indian faculty members; enroll in a school with expanded programs (e.g., late class times, online classes); have access to resources for issues like childcare; and meet with advisors and mentors to provide guidance and emotional support. Based on 12 case studies of American Indian students at a TCU, Crampeau (2015) found similar results. Participants identified several factors that they believed contributed to their success: instructor/faculty dedication and mentoring, family support for educational goals, proximity to home and family, and access to institutional resources, such as tutoring and internships.

In general, findings from tribal colleges echo the conclusions regarding retention of American Indian students in PWIs, and a number of themes become clear from the literature. Family/ tribal support and proximity to their community of origin reduced "pull” factors that may reduce persistence (e.g., Ness, 2002). Feelings of community among other students facilitated social integration and eased the transition into college (e.g., Thompson, Johnson- 
Jennings, \& Nitzarim, 2013). Positive interactions with faculty, staff, and mentors were also found to be vital to student success (Gloria \& Kurpius, 2001). A number of additional variables have been found to predict persistence in American Indians as well as for White students, for instance enjoyment of their college, volunteerism, and school pride and involvement (Pascarella \& Terenzini, 1980). Starting with these factors and under the general framework provided by Tinto’s $(1975,1994)$ student integration model, the current study aims to address an important gap in the literature by developing a statistical model to predict American Indian student persistence at a tribal University.

\section{Method}

This section contains the procedures used to gather the data for this project, and demographic information about the participants. The instruments used for the survey are described, and the dependent and outcome variables are defined.

\section{Procedures}

The research process was initiated after one of the authors was contacted by the administration of an area TCU to assess ongoing retention issues. The study was thus conducted with the aid and consultation of the administration at the institution from which the sample was drawn, and received approval through the governing Institutional Review Boards and from the Indigenous community within which the TCU was located and chartered. All participants consented to researchers accessing their academic records through the university registrar. Participants were recruited from a mandatory firstyear seminar. The survey was administered in October (approximately 2 months after attending classes) by trained graduate student researchers. 


\section{Participants}

Participants were American Indian students $(\mathrm{N}=89)$ enrolled in a freshman orientation seminar at a 4-year tribal university in the Midwestern United States. The university sustains a tribally diverse student body of approximately 900 students, representing over 150 federally recognized tribes from across the United States, including Alaska. The most common tribal affiliations are the Navajo Nation, representing $14.7 \%$ of the student body, and the Cherokee Nation, representing $11.9 \%$ of the student body. No other tribe represents more than $5 \%$ of the student body. The university offers Associate’s and Bachelor’s degrees. There is no required minimum GPA, so students with academic difficulties are considered on an individual basis.

The 89 participants represent $41 \%$ of the entire freshman class and include 34 women (38\%) and 55 men (62\%), with a mean age of $19.47(\mathrm{SD}=4.48)$. Most were single $(96 \%)$ and living on campus (92\%). Students reported that they grew up in large cities (12.5\%), suburbs (6.8\%), small towns (38.6\%), or reservations (40.7\%). Fifty students (55\%) have homes that are greater than 500 miles away from the university. A number of students ( $n=26 ; 29 \%)$ reported attending at least one college previously. Fifteen students (17\%) of the sample were first generation college students. All participants reported having one parent who identifies as American Indian; 73 (82\%) reported having mothers that identify, and 57 (64\%) reported having fathers that did so. When asked about the total household income of their family, $4.5 \%$ of the students reported below $\$ 20,000,21.3 \%$ between $\$ 20,000$ and $\$ 40,000,16 \%$ between $\$ 40,000$ and $\$ 60,000,25 \%$ between $\$ 60,000$ and $\$ 90,000,25 \%$ above $\$ 90,000$, and $25 \%$ did not know. Student resources were also examined: 14 (15.4\%) of the students have jobs, 41 (45\%) own a car, 11 (12.1\%) receive funding from the university, and 46 (50.5\%) receive funding from their tribes. 
The outcome variable for this study, persistence, was operationalized as enrollment for the fall semester of their second year; one calendar year (or two academic semesters) after the survey was administered. In the sample of 89 students, 49 (55.7\%) enrolled for their second year of college.

\section{Measures}

The First-Year Questionnaire for American Indians (FYQ-AI) was designed to inventory first-year students’ college experiences. The questionnaire consisted of 116 Likert-scaled (1 to 7) items assessing psychological, social, and cultural adjustment variables based on the previous literature. These items were then factor analyzed by Motl et al. (2009) to produce 12 discrete factors. The following are short descriptions of these factors.

Educational importance (five items; $\boldsymbol{\alpha}=$.77). Motivation to succeed at school, having high educational aspirations, and understanding how education will influence life and occupational goals. Higher scores reflect greater importance of education.

Educational challenge (two items; $\alpha=.72$ ). Feeling overwhelmed by academics. High scores reflect greater distress regarding amount or rigor of schoolwork.

Instructor concern (two items; $\boldsymbol{\alpha}=\mathbf{. 8 9}$ ). Belief that faculty care about the personal and academic success of students. Higher scores indicate feeling more support from instructors.

Enjoyment of college environment (four items; $\alpha=.79$ ). General enjoyment of the atmosphere and activities on campus; finding college “fun.” Higher scores reflect greater happiness in college environment. 
Social groups at college (three items; $\alpha=.84)$. Having friends and identifying with other students at college. Higher scores reflect greater social comfort.

Trust of others at college (six items; $\alpha=.79$ ). Trust of individuals who represent the institution, such as other students, faculty, administration, and security personnel. Higher scores reflect a greater general trust.

Fairness at college (five items; .95). Believing that others at college treat the individual fairly, politely, and are honest with the student. Higher scores indicate greater perceptions of fairness.

Respect at college (six items; $\alpha=.95$ ). Believing that the college community values, respects, and accepts the student. Higher scores indicate greater perceptions of respect.

School pride (two items; $\boldsymbol{\alpha}=.75$ ). Affiliation with the university and taking pride in student membership. Higher scores reflect more positive emotions about university association.

Campus involvement (four items; $\boldsymbol{\alpha}=\mathbf{. 6 9}$ ). Engaging in on-campus activities, such as student organizations, athletics, and cultural/ sports events. Higher scores indicate more involvement.

Longing for home (two items; $\boldsymbol{\alpha}=$.53). Homesickness and a desire to return to their community of origin. Higher scores reflect more longing for home.

Pressure from home (three items; $\boldsymbol{\alpha}=.74)$. Social pressure or implied responsibility to depart school prior to graduation. Higher scores indicate more pressure.

Intent to persist (one item). Confidence in completing a degree from this institution. 
The Hope Scale (Snyder et al., 1991) was also administered in order to assess students' sense of agency when pursuing goals as well as their ability to enact strategies to overcome obstacles in pursuit of those objectives. The Hope Scale contains 12 items, has demonstrated sufficient reliability ( $\alpha=.81$ ), and has been related to academic success among college students (Snyder et al., 2002).

Variables indicating academic preparation (high school GPA and high school class percentile), academic integration (first and second semester GPAs), and persistence (second-year enrollment) were obtained directly from the university registrar. Greater high school class percentiles indicate better performance relative to peers. This metric should be interpreted as "the student had a higher class ranking than X\% of their graduating class” (see Table 1 for alpha coefficients, number of items, means, standard deviations for all variables employed in this study).

\section{Results}

To determine which factors influence persistence in this sample, the data were analyzed using a logistic regression. The goal of a logistic regression is to predict the category of an outcome for each particular case based on a set of predictive factors. These predictions can be compared to observed outcomes to determine the degree to which the factors predict the outcomes of interest as well as the relative value of each factor (Tabachnick \& Fidell, 2007). A logistic regression will yield an odds ratio for each variable; odds ratios greater than one indicate a greater chance of persistence as that variable increases, and those less than one indicate a declining chance of persistence as that variable increases. In the current study, researchers constructed a statistical model with the goal of correctly categorizing students into persister and nonpersister categories. Predictor variables were divided into three blocks: a block containing 
Table 1

Statistics for Variables of Interest $(N=89)$

\begin{tabular}{|c|c|c|c|c|}
\hline Variable & Example item & \# of items & $\alpha$ & $M(S D)$ \\
\hline High school GPA & From university records & 1 & - & $2.72(.38)$ \\
\hline High school class percentile & From university records & 1 & - & $47 \%(24)$ \\
\hline College GPA, first semester & From university records & 1 & - & $2.66(.86)$ \\
\hline College GPA, second semester & From university records & 1 & - & $1.62(1.27)$ \\
\hline Educational importance $^{\mathrm{a}}$ & I attend all my classes. & 5 & .77 & $5.29(1.14)$ \\
\hline Educational challenge $^{\mathrm{a}}$ & Schoolwork here is much harder than high school. & 2 & .72 & $3.87(1.65)$ \\
\hline Instructor concern ${ }^{\mathrm{a}}$ & $\begin{array}{l}\text { The instructors here are concerned with my academic } \\
\text { success. }\end{array}$ & 2 & .89 & $4.63(1.64)$ \\
\hline $\begin{array}{l}\text { Enjoyment of college } \\
\text { environment }^{\mathrm{a}}\end{array}$ & I enjoy my current living situation. & 4 & .79 & $5.30(1.30)$ \\
\hline Social groups at college ${ }^{\mathrm{a}}$ & I feel close to other students at this school. & 3 & .84 & $4.39(1.47)$ \\
\hline Trust of others at college ${ }^{a}$ & How much do you trust professors at this school? & 6 & .79 & $4.87(1.22)$ \\
\hline Longing for home ${ }^{\mathrm{a}}$ & I often get homesick. & 2 & .53 & $4.71(1.61)$ \\
\hline Pressure from home ${ }^{a}$ & I have many responsibilities at home. & 3 & .74 & $5.96(1.29)$ \\
\hline Fairness at college $^{\mathrm{a}}$ & Others at this school treat me fairly. & 10 & .95 & $4.99(1.20)$ \\
\hline Respect at college ${ }^{a}$ & $\begin{array}{l}\text { If they knew me, people at this school would respect } \\
\text { my achievements. }\end{array}$ & 10 & .95 & $5.67(1.05)$ \\
\hline Campus involvement $^{\mathrm{a}}$ & I like to spend most of my free time on campus. & 4 & .69 & $4.68(1.15)$ \\
\hline School pride ${ }^{\mathrm{a}}$ & I talk up this university to others. & 2 & .75 & $5.49(1.28)$ \\
\hline Intent to persist ${ }^{\mathrm{a}}$ & $\begin{array}{l}\text { I am confident I will complete a degree from this } \\
\text { institution. }\end{array}$ & 1 & - & $5.60(1.88)$ \\
\hline Hope scale & I energetically pursue my goals. & 12 & .81 & $24.86(4.57)$ \\
\hline $\begin{array}{l}\text { Student enrollment in second } \\
\text { year }\end{array}$ & From university records & \multicolumn{3}{|c|}{$\begin{array}{l}\text { Enrolled: } n=50(56.2 \%) \\
\text { Not enrolled: } n=39(43.8 \%)\end{array}$} \\
\hline
\end{tabular}

${ }^{a}$ Response options range from 1 (strongly disagree) to 7 (strongly agree).

academic preparation variables, a block containing academic integration variables, and a block containing psychosociocultural integration variables. The 12 psychosociocultural factors

identified through factor analysis were all considered for inclusion. Three models were created and compared based on these blocks. By examining the data in this way, the unique contribution of each block can be assessed after accounting for the other variables in the model. Model 1 contains variables indicative of academic preparation: high school GPA and graduating class percentile. The overall model is significant, $\mathrm{R}^{2}=.15, \mathrm{X}^{2}(2, \mathrm{~N}=89)=10.28, \mathrm{p}=.006$, and represents an increase in correct prediction from 56.2\% (base rate) to 62.9\%. Model 2 contains the variables from Model 1 as well as variables indicative of academic integration to college: first- and second-semester college GPAs. Model 2 is statistically significant overall, $\mathrm{R}^{2}=.53$, $\mathrm{X}^{2}(5, \mathrm{~N}=89)=45.05, \mathrm{p}<.001$, and represents an increase in correct prediction from $62.9 \%$ 
(Model 1) to 79.8\%. Model 3 contains Models 1 and 2, as well as factors indicative of psychosociocultural integration to the college environment. The third model is statistically significant overall, $\mathrm{R}^{2}=.72, \mathrm{X}^{2}(12, \mathrm{~N}=89)=70.00, \mathrm{p}<.001$, and represents an increase in correct prediction from 79.8\% (Model 2) to 89.9\%. Importantly, psychosociocultural integration was found to add a significant amount of predictive power to the regression equation above and beyond that explained by academic preparation and academic performance, $\Delta \mathrm{R}^{2}=.19, \Delta \mathrm{X}^{2}(9$, $\mathrm{N}=89$ ) $=23.66, \mathrm{p}=.005$ (see Table 2 for a summaries of these models and fit statistics).

Three psychosociocultural factors—social groups at college, respect from others, and campus involvement—as well as students' intent to persist until graduation, were omitted because their statistical contribution was neither significant independently and nor did it increase model fit in the context of the other factors. Three other factors-instructor concern, pressure

Table 2

Comparison of Logistic Regression Models

\begin{tabular}{|c|c|c|c|c|c|c|}
\hline \multirow[b]{2}{*}{ Variable } & \multicolumn{2}{|c|}{ Model 1} & \multicolumn{2}{|c|}{ Model 2} & \multicolumn{2}{|c|}{ Model 3} \\
\hline & Odds & Wald & Odds & Wald & Odds & Wald \\
\hline High school GPA & 5.29 & $5.79^{*}$ & 4.75 & 3.43 & 3.06 & .96 \\
\hline High school class percentile & .96 & $8.61^{* *}$ & .94 & $9.98^{* *}$ & .94 & $6.41^{*}$ \\
\hline College GPA, first semester & - & - & 1.28 & .37 & 1.07 & .02 \\
\hline College GPA, second semester & - & - & 3.68 & $17.49^{* *}$ & 10.23 & $15.83^{* *}$ \\
\hline Educational importance & - & - & - & - & 4.07 & $4.71^{*}$ \\
\hline Instructor concern & - & - & - & - & .68 & 1.75 \\
\hline Enjoyment of college environment & - & - & - & - & .50 & 2.68 \\
\hline Longing for home & - & - & - & - & .37 & $7.23^{* *}$ \\
\hline Trust of others at college & - & - & - & - & .17 & $5.14^{*}$ \\
\hline Pressure from home & - & - & - & - & 1.80 & 2.67 \\
\hline Fair treatment by others & - & - & - & - & 2.87 & $3.97^{*}$ \\
\hline School pride & - & - & - & - & 3.35 & $5.10^{*}$ \\
\hline Hope & - & - & - & - & .76 & $4.76^{*}$ \\
\hline (Constant) & - & $6.75^{* *}$ & - & $8.15^{* *}$ & - & .97 \\
\hline Nagelkerke $R^{2}$ & \multicolumn{2}{|c|}{$.15^{* *}$} & \multicolumn{2}{|c|}{$.53^{* *}$} & \multicolumn{2}{|c|}{$.72^{* *}$} \\
\hline$\%$ Correctly predicted & \multicolumn{2}{|c|}{$62.9 \%$} & \multicolumn{2}{|c|}{$79.8 \%$} & \multicolumn{2}{|c|}{$89.9 \%$} \\
\hline
\end{tabular}

${ }^{*} p<.05 .{ }^{* *} p<.01$. 
from home, and enjoyment of the college environment—have been supported by previous research (e.g., Brown \& Robinson Kurpius, 1997), and were included in the model because they increased the predictive capacity of the model overall despite the fact that they were not statistically significant predictors of student retention on their own. Thus, Model 3 is the product of balancing interpretable, theory-driven factors with those supported by statistical criteria available from this sample. Thirteen variables were included in the final model (see Table 3 for intercorrelations of these variables).

In the final model (Model 3; see Table 2), the academic variables found to be associated with increased college persistence were higher second semester college GPAs and lower high school class percentile. Among psychosociocultural variables, valuing the importance of education, not being homesick, being treated fairly by faculty and students at college, and school pride were all significantly associated with persistence. High levels of trust of others at college and high levels of hope, as indicated by the Hope Scale (Snyder et al., 1991), were both found to significantly predict college nonpersistence.

Table 3

Intercorrelations Between Variables in the Final Logistic Regression Model

\begin{tabular}{|c|c|c|c|c|c|c|c|c|c|c|c|c|}
\hline Variable & 1 & 2 & 3 & 4 & 5 & 6 & 7 & 8 & 9 & 10 & 11 & 12 \\
\hline 1. High school GPA & - & & & & & & & & & & & \\
\hline 2. High school class percentile & $.69^{* *}$ & - & & & & & & & & & & \\
\hline 3. College GPA, 1st semester & .10 & .10 & - & & & & & & & & & \\
\hline 4. College GPA, 2nd semester & .18 & .08 & $.49^{* *}$ & - & & & & & & & & \\
\hline 5. Educational importance & .09 & .07 & .06 & .10 & - & & & & & & & \\
\hline 6. Instructor concern & -.01 & -.11 & -.13 & .04 & $.42^{* *}$ & - & & & & & & \\
\hline $\begin{array}{l}\text { 7. Enjoyment of college } \\
\text { environment }\end{array}$ & .09 & -.01 & .01 & .13 & $.58^{* *}$ & $.33^{* *}$ & - & & & & & \\
\hline 8. Longing for home & -.01 & .15 & -.12 & -.15 & .20 & -.14 & -.04 & - & & & & \\
\hline 9. Trust of others at college & -.03 & -.11 & -.03 & .09 & $.37^{* *}$ & $.39^{* *}$ & $.40^{* *}$ & .01 & - & & & \\
\hline 10. Pressure from home & .12 & -.02 & -.11 & .09 & -.19 & .07 & -.10 & .02 & $-.26^{*}$ & - & & \\
\hline 11. Fair treatment by others & .09 & -.02 & .01 & .04 & $.35^{* * *}$ & .11 & $.32^{* *}$ & -.01 & $.59^{* *}$ & $-.25^{*}$ & - & \\
\hline 12. School pride & -.02 & -.08 & .08 & .05 & $.23^{*}$ & .15 & $.38^{* *}$ & -.10 & $.23^{*}$ & -.11 & .18 & - \\
\hline 13. Hope & -.05 & -.01 & .15 & $.23^{*}$ & .10 & .10 & .09 & $.23^{*}$ & .07 & -.14 & .17 & $.31^{* *}$ \\
\hline
\end{tabular}


To clarify the interpretation of some findings, follow-up independent samples $t$ tests were performed to determine if persisters $(n=50)$ differed from nonpersisters $(n=39)$ in specific variables of interest. Though, on average, persisters reported less trust in individuals at college $(M=4.77, S D=1.38)$ than did nonpersisters $(M=4.98, S D=1.03)$, less hope $(M=24.84, S D=$ 4.95) than did nonpersisters ( $M=24.96, S D=4.16)$, and a lower high school class percentile ranking $(M=43.66, S D=22.59)$ than did nonpersisters $(M=51.96, S D=24.29)$, the differences between groups were not statistically significant. However, persisters $(M=2.89, S D=.65)$ did have significantly higher first semester GPAs than did nonpersisters ( $M=2.36, S D=.93), t(87)$ $=2.99, p=.004$. Persisters $(M=2.26, S D=.97)$ also had significantly higher second semester GPAs than did nonpersisters $(M=.80, S D=1.08), t(87)=6.69, p<.001$. In addition, students who persisted into their second semester reported a significantly greater intent to persist $(M=$ $6.06, S D=1.71)$ during their first semester of school than did nonpersisters $(M=5.03, S D=$ 2.07), $t(87)=2.30, p=.011$.

\section{Discussion}

Of the 89 participants in this study, just over 56\% were retained into their second year. This is above the historical first-year retention rate — approximately $45 \%$ —for this population (Wells, 1997). The variables used to differentiate the persisters from the nonpersisters represent an empirically based, holistic appraisal of those factors affecting American Indian persistence behaviors. The final model (see Table 2) incorporates high school academic ability variables (i.e., high school GPA and high school class percentile), academic integration variables (i.e., college GPA), and selected psychosociocultural integration variables (e.g., trust of others on campus, school pride, and longing for home). This model successfully accounts for $72 \%\left({ }^{R 2}=\right.$ .72; a large effect) of the variance associated with persistence from the first to the second year of 
college, and correctly classified almost $90 \%$ of the students in the sample. Thus, it can be considered an accurate representation of many of the factors that have influenced persistence among students in this sample. In general, this model suggests that academic preparation, academic integration, and psychosociocultural integration all play important roles in the persistence decisions made by these students.

\section{Academic Preparation}

Students arrive at college with certain levels of academic preparation, and this characteristic is often used as a metric for admission decisions. Previous studies have found that it influences student retention (e.g., Brown \& Robinson Kurpius, 1997), and may be especially important for American Indian students (Jenkins, 1999). The current study found that high school graduating class percentile was more predictive of retention than high school GPA. The current results, however, indicate that this relationship works in the opposite direction than would be hypothesized based on the previous research (e.g., Brown \& Robinson Kurpius, 1997). In the current sample, student persistence was associated with lower percentile rankings (worse relative performance). Interestingly, better relative high school performance predicted a poorer chance of persistence into the second year of college. This association was found to have a small but stable effect within this sample.

One plausible explanation for this finding is that retention studies such as this may not be able to measure persistence cross-institutionally. Although a student may not persist at a particular school, it is possible they may have transferred to a different institution, which may be falsely recognized as nonpersistence. Students who performed well in high school (i.e., those with higher high school class percentiles) may have more of such opportunities than their poorer performing counterparts. Although this may be the case for an occasional student, an 
examination of this sample does not support this contention in general. Primarily, there is no relationship between academic preparation variables (high school class percentile and GPA) and academic performance variables (college GPAs). Table 3 provides more information. Based on these findings, it appears as though students who were more academically prepared, as per their high school class percentile, underperformed academically once they entered college. The nonassociation between these constructs highlights the distinction between academic preparation and academic integration. Furthermore, persisters in this sample outperformed nonpersisters in both first and second semester GPA. Only two nonpersisters had GPAs above 3.0, compared with 16 persisters.

As such, the data support the conclusion that students who performed well in relation to classmates in high school had a more difficult time integrating academically into the college environment, received poorer grades, and were less likely to persist. Academic success in high school simply did not translate to academic success in college for some American Indian students at this TCU.

\section{Academic Integration}

Academic success in high school was not related to academic success during the first year of college. Results suggest that if the academic environment on campus does not support success (at least in terms of GPA), the likelihood of persistence declines sharply. College GPAs, especially those earned most recently, help predict whether or not a student will be retained. Academic integration, measured in this way, adds a crucial element to understanding student persistence behaviors. As this TCU does not have definitive academic thresholds for suspension or dismissal of students who are struggling academically, student GPAs, even if very low, are rarely the sole factor for student nonpersistence at this university. 
However, the link between college GPA and persistence must be interpreted with caution. Semester GPAs do not represent a full semester of work for every student, and are not perfect indicators of academic engagement. As the semester progresses, unofficial withdrawals from some or all classes become increasingly likely as a result of discouragement or external influences. A larger proportion of nonpersisters $(n=22)$ completed the semester with a 0.0 GPA (failing all classes) than persisters $(n=3)$. Though second-semester GPA does suggest the student has disengaged, it may not fully capture how or why this has occurred. For some students, poor academic performance may be an effect of nonpersistence rather than a cause of it.

\section{Psychosociocultural Integration}

Psychosociocultural integration was captured through 12 variables indicative of psychological and social adjustment to the college environment. How well a student integrated into campus during the first two months of their first year was unrelated to high school or college academic performance. These psychosociocultural integration factors predict 1-year college persistence behaviors in American Indians students even after accounting for both academic preparation and academic performance. No matter how well prepared the student or how much academic success they enjoy while at college, psychosociocultural factors have a large impact on student persistence.

The current study does not distinguish between students who departed voluntarily and those that withdrew because of academic difficulties. Previous models, for example Tinto's (1975, 1994) model of student departure, encapsulate only those students who exit school voluntarily. By not making this distinction (these data were not available), the current study likely inflates the relative importance of academic preparation and performance variablesparticularly second-semester GPA. Nonetheless, psychosociocultural integration was still found 
to be predictive above and beyond these factors, and suggests that it is an important and multifaceted construct for American Indian students at a TCU, regardless of academic background and current success.

Furthermore, psychosociocultural variables were assessed when students had been enrolled for less than 2 months. Their contribution to the model suggests that the factors that compose to a student's psychological orientation to the collegiate experience are formed early in the student's academic career. Persistence is largely contingent upon attitudes formed during or before the students’ first few months on campus.

Some of the assessed psychosociocultural factors were found to be particularly predictive of student retention after accounting for the variance associated with academic preparation and integration. Commensurate with previous studies (e.g., Brown \& Robinson Kurpius, 1997), student orientation to education and academic attainment were found to be significant. Students who value a postsecondary education, take their academic responsibilities seriously, and put forth more academic effort are more likely to be enrolled in their second year than those who do not. Longing for home was found to be an important factor in student persistence. Students who perceived the collegiate environment to be similar to their community of origin, and those who experienced less homesickness were considerably more likely to persist. In fact, level of longing for one's home appears to be among the most powerful predictors of persistence. The level of distress associated with being away from home was much more predictive of persistence than the level of enjoyment found at college.

The construct of fair treatment by others emerged as a significant predictor of persistence. The more a student sees the campus community as a thoughtful, concerned, and respectful group, and the college as a just institution, the greater the likelihood they will persist. In other words, 
students who believe their hard work, in both academic and social spheres, will be rewarded by the college environment are more likely to remain in that environment. School pride, in the form of volunteerism and promotion of the benefits of attendance at the college, was likewise found to be a significant predictor of enrollment.

Two other factors, trust of others at college and hope, were also found to be predictive of student retention in the context of the final model, but in the opposite direction than was expected. Persisters seemed to have lower levels of trust in others at college and hope than did nonpersisters, although this difference was not statistically significant. In the context of the regression, however, both emerged as significant predictors of student persistence. Greater levels of both trust in others and hope were found, counterintuitively, to be predictive of student departure. More trust in students, faculty and the institution decreased the likelihood that students would persist into their second year of college. Likewise, more hope, as defined by Snyder et al. (1991), was associated with a greater likelihood of nonpersistence.

Research uncovered no precedent in the literature to account for these findings. It is possible that persistent students were not less hopeful, but simply more accurate in their assessment of their ability to find avenues toward their goals (pathways) and move with those intentions (agency), which are the two components of hope (Snyder et al., 1991). Nonpersisters may have unrealistically favorable appraisals of their own abilities. They would therefore have failed to appreciate the challenges they face, and their own ability to confront them. Previous research has found that some American Indian students may have difficulty assessing their own academic abilities (Hoover \& Jacobs, 1992), which may contribute to this effect.

The inverse relationship between student trust of others at school and persistence is also surprising. One plausible explanation is that some students, especially nonpersisters, may 
conflate the concept of trust in the institution, and the concept of entitlement to the benefits offered by that institution. Some students enter college under the belief that educational institutions will ensure good grades, enrollment status, and eventually graduation with little effort or exertion by the student (Chowning \& Campbell, 2009). These students blindly trust that the institution will advance their academic pursuits regardless of student input. Attitudes of academic entitlement have been found to be negatively correlated with academic self-efficacy (Boswell, 2012) and academic success (Jeffres, Barclay, \& Stolte, 2014) in the general population of college students. This interpretation is supported by the fact that the trust factor was inversely associated with persistence, while the fairness factor was directly associated with persistence. When students perceived that they were fairly treated, then they were likely to persist; when students perceived they were entitled to success, they were not.

Another possible explanation is that students who formed trusting relationships with faculty, staff, administrators, and peers are more likely to be privy to and influenced by the advice and sentiments of those individuals. These individuals therefore have leverage over the decisions made by the students. If these school representatives support and promote the university, its policies, and the students' enrollment at the institution, then such trust will likely result in persistence. However, if trusted representatives seem to have an unfavorable attitude toward the institution, its policies, and/or its community — then these types of relationships may contribute to student attrition.

Interaction with faculty members was not found to be a significant predictor of retention by itself. It was included in the model because there a substantial amount of research supporting the idea that positive interactions between students and faculty tend to be associated with persistence. This factor was also found to decrease (albeit not significantly so) the likelihood of 
student persistence; a finding that may be related to the types of relationships described previously.

Students who entered school with greater intent to persist at the university until graduation were more likely to be retained into their second year. However, the effect of this variable was not significant when included in the context of the final model, suggesting that though student intention to persevere until graduation is important, it does not exert an effect that is unique from psychosociocultural integration. Student intention to complete a degree at an institution is predictive of retention only inasmuch as the collegiate environment supports that student's social and academic integration into the learning community.

\section{Limitations}

There are several limitations to this study. First, this study includes only one institution, and thus generalizations to American Indian students in other TCUs or PWIs should be made cautiously. However, this particular TCU is highly diverse, including over 150 tribes. In addition, voluntary and involuntary nonpersisters could not be distinguished. The university does not require exit interviews and has no definitive rules for academic dismissal. Furthermore, due to the minimal financial cost associated with attending tribal colleges (i.e., extremely low tuition, if any), most students do not have incentives to officially withdraw in order to have tuition refunded. There are certainly systematic differences between students who depart voluntarily after the end of a semester or due to external factors (e.g., family reasons), and those who stop attending because they feel overwhelmed by the material. Having this data may add to the interpretations drawn from this sample. 
Another limitation is that students were surveyed in early October of their first year in school. Many students have already dropped out of school at the time of contact. Also, the sample consisted of $41 \%$ of all matriculating students. Researchers entered classes to administer the survey, so students who were absent that day did not complete the survey. Chronic or occasional absentees were likely to be underrepresented in the sample. As such, this sample may represent students who are already more likely to persist and attend classes.

Finally, in order to gain an inclusive perspective, all research decisions were made in consultation with American Indian administrators of the institution, community leaders and scholars. Nonetheless, the choice of variables, instruments, method of analysis, interpretation, and reporting reflect a specific orientation to the research question—one that may also reflect the epistemological stance and cultural background of the researchers. Furthermore, it is also possible that the gender and ethnicity of the graduate research assistants who administered the instruments could have influenced the survey responses, though it should be noted that the instructor remained in the classroom during survey administration. The findings of the current study should be interpreted with these considerations in mind.

\section{Conclusion and Future Directions}

First-year students at a tribal university were surveyed regarding psychosociocultural integration factors during the first 2 months at school. These, along with variables indicative of academic preparation and integration were analyzed to determine which successfully which students were enrolled at the beginning of their second year. This was the first known empirical study of persistence of American Indian students to include an actual measure of persistence rather than just an intent to persist. The data yielded a number of valuable conclusions. First, when taken together, factors indicative of academic preparation, academic integration and 
psychosociocultural integration can create a model that is able to predict a large proportion of the variance associated with objective measures of student persistence at a tribal college. A model was created that correctly classified $89.9 \%$ of the 89 students in this sample. Surprisingly, greater academic preparation as indicated by one's percentile class rank in high school, decreased the likelihood of persistence for participants in this sample. Successful academic integration, in the form of college GPA, increased the likelihood of persistence. Academic preparation and academic integration variables were not correlated.

Psychosociocultural integration was found to be predictive of persistence even after accounting for academic preparation and academic integration/ performance. Discrete factors that were found to be important in student retention were: (a) placing a value on education; (b) not being homesick; (c) finding the college community to be fair, concerned and respectful; and (d) being proud of one's affiliation with their university. These attitudes are formed early; before the end of the first 2 months on campus. Interestingly, trust of others on campus and level of hope were found to be predictive of student persistence, but in the opposite direction than researchers hypothesized. Increases in hope and trust decreased the likelihood students would persist.

Thus, these findings may be summarized in terms of protective and risk factors. Students are protected from attrition when they (a) can relate their academic trajectories with life goals and values, (b) feel as though the social and academic effort they exert is fairly rewarded, and (c) have made an emotional investment in the institution and have incorporated this effort into their growing identities. Students are vulnerable to attrition when they (a) are often homesick, (b) blindly trust the institution to ensure their success, and (c) have unrealistic appraisals of their own abilities to attain goals or the difficulty of collegiate success. 
Future research should further examine or attempt to replicate the unexpected findings; particularly the results that suggest high levels of trust and hope may disrupt collegiate persistence at TCUs. In addition, this sample consists of a highly diverse sample of students based on tribal affiliation. Though attending a tribal college may ease cultural integration factors compared with American Indian students at PWIs, American Indian students at a tribal college do not necessarily represent a homogenous sample. Finding more effective ways of measuring psychosociocultural integration in specific subpopulations like those at tribal colleges, may help researchers better identify psychosociocultural integration factors.

These findings suggest a number of policy and program recommendations. Programs designed to increase the psychosociocultural factors found to be most important can be developed or adopted. For instance, institutions may be well served to implement programs intended to effectively describe the importance of education in relation to specific occupational and personal goals of each student. Explicit goals to foster a sense of school pride, fair treatment, mutual concern, and respectful discourse are also likely to be helpful. Particularly for this population, it would behoove colleges to reduce barriers to open communication and travel between students and their families in order to reduce homesickness and estrangement from one's community of origin. 


\section{References}

Ah Nee-Benham, M. K. P. (2003). The journey of the

Native American higher education initiative and tribal colleges and universities. In M. K. P. Ah Nee-Benham \& W. J. Stein (Eds.), The renaissance of American Indian higher education: Capturing the dream (pp. 3-25). Mahwah, NJ: Erlbaum.

American Indian Higher Education Consortium. (2012). 2009 -2010 AIHEC AIMS fact book: Tribal colleges and universities report. Retrieved from http://www.aihec.org/ourstories/docs/reports/AIHEC_AIMSreport_May2012.pdf

American Psychological Association. (2009). Publication manual of the American Psychological Association (6th ed.). Washington, DC: American Psychological Association.

Astin, A. W. (1982). Minorities in American higher education: Final report of the Commission on the Higher Education of Minorities. San Francisco, CA: Jossey-Bass.

Boswell, S. S. (2012). I deserve success: Academic entitlement attitudes and their relationships with course self-efficacy, social networking, and demographic variables. Social Psychology of Education, 15, 353-365. http://dx.doi.org/10.1007/s11218-012-9184-4

Brown, L. L., \& Robinson Kurpius, S. E. (1997). Psychosocial factors influencing academic persistence of American Indian college students. Journal of College Student Development, 38, 3-12.

Chowning, K., \& Campbell, N. J. (2009). Development and validation of a measure of academic entitlement: Individual differences in students’ externalized responsibility and entitled expectations. Journal of Educational Psychology, 101, 982-997. http://dx.doi.org/10.1037/a0016351

Crampeau, A. M. (2015). The experience of American Indian students regarding their perceptions of postsecondary education at a tribal college in the Midwest (Doctoral Dissertation). Retrieved from UMI (3704227).

Crissman Ishler, J. L., \& Upcraft, M. L. (2004). The keys to first-year student persistence. In M. L. Upcraft, J. N. Gardner, \& B. O. Barefoot (Eds.), Challenging and supporting the first- 
year student: A handbook for improving the first year of college (pp. 27-46). San Francisco, CA: Jossey-Bass.

Freeman, C., \& Fox, M. (2005). Status and trends in education of American Indians and Alaska Natives (NCES 2005-108). Washington, DC: U.S. Government Printing Office.

Gloria, A. M., \& Kurpius, S. E. (2001). Influences of self-beliefs, social support, and comfort in the university environment on the academic nonpersistence decisions of American Indian undergraduates. Cultural Diversity \& Ethnic Minority Psychology, 7, 88-102. http://dx.doi.org/10.1037/1099-9809.7.1.88

Gloria, A. M., \& Rodriguez, E. R. (2000). Counseling Latino university students: Psychosociocultural issues for consideration. Journal of Counseling \& Development, 78, 145-154. http://dx.doi.org/10.1002/j.1556-6676.2000.tb02572.x

Guiffrida, D. A. (2006). Toward a cultural advancement of Tinto's theory. Review of Higher Education, 29, 451-472. http://dx.doi.org/10.1353/rhe.2006.0031

Guiffrida, D. A., Marquez Kiyama, J., Waterman, S. J., \& Museus, S. D. (2012). Moving from cultures of individualism to cultures of collectivism in support of students of color. In S. D. Museus \& U. M. Jayakumar (Eds.), Creating campus cultures: Fostering success among racially diverse student populations (pp. 68-87). New York, NY: Routledge.

Guillory, R. M. (2009). American Indian/Alaska native college student retention strategies. Journal of Developmental Education, 33, 12-38.

Guillory, R. M., \& Wolverton, M. (2008). It’s about family: Native American student persistence in higher education. The Journal of Higher Education, 79, 58 - 87. http://dx.doi.org/10.1353/jhe.2008.0001

Hoover, J. J., \& Jacobs, C. C. (1992). A survey of American Indian college students: Perceptions toward their study skills/college life. Journal of American Indian Education, 32, 21-29.

Huffman, T., \& Ferguson, R. (2007). Evaluation of the college experience among American Indian Upperclassmen. Great Plains Research, 17, 61-71. 
Jackson, A. P., Smith, S. A., \& Hill, C. L. (2003). Academic persistence among Native American college students. Journal of College Student Development, 44, 548 -565. http://dx.doi.org/10.1353/csd.2003.0039

Jeffres, M. N., Barclay, S. M., \& Stolte, S. K. (2014). Academic entitlement and academic performance in graduating pharmacy students. American Journal of Pharmaceutical Education, 78, 116. http://dx.doi.org/10.5688/ajpe786116

Jenkins, M. (1999). Factors which influence the success or failure of American Indian/Native American college students. Research \& Teaching in Developmental Education, 15, 4954.

Kenny, M. E., \& Stryker, S. (1996). Social network characteristics and college adjustment among racially and ethnically diverse first-year students. Journal of College Student Development, 37, 649-658.

Larimore, J., \& McClellan, G. (2005). Native American student retention in U.S. postsecondary education. In M. Tippeconnic Fox, S. Lowe, \& G. McClellan (Eds.), Serving Native American students: New directions for student services (pp. 17-32). San Francisco, CA: Jossey-Bass.

Lundberg, C. (2007). Student involvement and institutional commitment to diversity as predictors of Native American student learning. Journal of College Student Development, 48, 405-417. http://dx.doi.org/10.1353/csd.2007.0039

Mallinckrodt, B. E. (1988). Student retention, social support, and dropout intention: Comparison of Black and White students. Journal of College Student Development, 29, 60-64.

Motl, T. C., Multon, K. M., Zhao, F., Haskell, B., Molina, L., Krogmann, M., .. Robinson, M. (2009, August). Factors associated with college persistence in first-year Native American students. Poster presentation at the American Psychological Association Convention, Toronto, Ontario, Canada.

Museus, S. D., Lam, S., Huang, C., Kem, P., \& Tan, K. (2012). Cultural integration in campus subcultures: Where the cultural, academic, and social spheres of college life collide. In S. 
D. Museus \& U. M. Jayakumar (Eds.), Creating campus cultures: Fostering success among racially diverse student populations (pp. 106-129). New York, NY: Routledge.

Ness, J. E. (2002). Crossing the finish line: American Indian completers and non-completers in a tribal college. Tribal College, 13, 36-41.

Nora, A. (2001). The depiction of significant others in Tinto's "rites of passage:” A reconceptualization of the influence of family and community in the persistence process. Journal of College Student Retention, 3, 41-56. http://dx.doi.org/10.2190/BYT5-9F057F6M-5YCM

Nora, A., \& Cabrera, A. F. (1996). The role of perceptions of prejudice and discrimination on the adjustment of minority students to college. The Journal of Higher Education, 67, 119148. http://dx.doi.org/10.2307/2943977

Okagaki, L., Helling, M. K., \& Bingham, G. E. (2009). American Indian college students’ ethnic identity and beliefs about education. Journal of College Student Development, 50, 157176. http://dx.doi.org/10.1353/csd.0.0060

Pascarella, E. T., \& Terenzini, P. T. (1980). Predicting freshman persistence and voluntary dropout decisions from a theoretical model. The Journal of Higher Education, 51, 60-75. http://dx.doi.org/10.2307/1981125

Patterson Cross, K. (2002). When and why American Indian/Alaska native students graduate: A longitudinal study of student persistence in a tribal college (Doctoral Dissertation). Retrieved from UMI (3086986).

Pavel, D. M., Inglebret, E., \& Banks, S. R. (2001). Tribal college and universities in an era of dynamic development. Peabody Journal of Education, 76, 50 -76. http://dx.doi.org/10.1207/S15327930PJE7601_04

Pottinger, R. (1989). Disjunction to higher education: American Indian students in the southwest. Anthropology \& Education Quarterly, 20, 326-344. http://dx.doi.org/10.1525/aeq.1989.20.4.04x0458p 
Richardson, M., Abraham, C., \& Bond, R. (2012). Psychological correlates of university students' academic performance: A systematic review and meta-analysis. Psychological Bulletin, 138, 353-387. http://dx.doi.org/10.1037/a0026838

Robbins, S. B., Lauver, K., Le, H., Davis, D., Langley, R., \& Carlstrom, A. (2004). Do psychosocial and study skill factors predict college outcomes? A meta-analysis. Psychological Bulletin, 130, 261-288. http://dx.doi.org/10.1037/0033-2909.130.2.261

Rousey, A., \& Longie, E. (2001). The tribal college as family support system. American Behavioral Scientist, 44, 1492-1504. http://dx.doi.org/10.1177/00027640121956926

Shotton, H. J., Oosahwe, E. S. L., \& Cintrón, R. (2007). Stories of success: Experiences of American Indian students in a peer-mentoring retention program. Review of Higher Education, 31, 81-107. http://dx.doi.org/10.1353/rhe.2007.0060

Snyder, C. R., Harris, C., Anderson, J. R., Holleran, S. A., Irving, L. M., Sigmon, S. T., . . . Harney, P. (1991). The will and the ways: Development and validation of an individualdifferences measure of hope. Journal of Personality and Social Psychology, 60, 570-585. http://dx.doi.org/10.1037/0022-3514.60.4.570

Snyder, C. R., Shorey, H. S., Cheavens, J., Mann Pulvers, K., Adams, V. H., III, \& Wiklund, C. (2002). Hope and academic success in college. Journal of Educational Psychology, 94, 820-826. http://dx.doi.org/10.1037/0022-0663.94.4.820

Stillwell, R., \& Sable, J. (2013). Public school graduates and dropouts from the common core of data: School year 2009-10: First look. U.S. Department of Education. Washington, DC: National Center for Education Statistics. Retrieved from http://nces.ed.gov/pubsearch

Tabachnick, B. G., \& Fidell, L. S. (2007). Using multivariate statistics (5th ed.). New York, NY: Pearson.

Terenzini, P. T., \& Pascarella, E. T. (1991). Twenty years of research on college students: Lessons for future research. Research in Higher Education, 32, 83-92. http://dx.doi.org/10.1007/BF00992835

Thompson, M. N., Johnson-Jennings, M., \& Nitzarim, R. S. (2013). Native American undergraduate students' persistence intentions: A psychosociocultural perspective. 
Cultural Diversity \& Ethnic Minority Psychology, 19, 218-228.

http://dx.doi.org/10.1037/a0031546

Tierney, W. G. (1992). An anthropological analysis of student participation in college. The Journal of Higher Education, 63, 603-618. http://dx.doi.org/10.2307/1982046

Tinto, V. (1975). Dropout from higher education: A theoretical synthesis of recent research. Review of Educational Research, 45, 89-125. http://dx.doi.org/10.3102/00346543045001089

Tinto, V. (1994). Leaving college: Rethinking the causes and cures of student attrition. Chicago, IL: University of Chicago Press. http://dx.doi.org/10.7208/chicago/9780226922461.001.0001

Wells, R. N. (1997). The Native American experience in higher education: Turning around the cycle of failure II. ERIC Document Reproduction Service ED, 414, 108. 